\title{
STANDARDY OCHRONY PRAW PODATNIKA W KARCIE PRAW PODSTAWOWYCH I ICH STOSOWANIE W ORZECZNICTWIE SĄDÓW ADMINISTRACYJNYCH
}

\section{WSTĘP}

Prawo podatkowe jest gałęzią prawa, której normy szczególnie intensywnie ingerują w sferę wolności jednostki. Koniecznym elementem każdego porządku prawnego zbudowanego z norm tego rodzaju są zatem mechanizmy ochrony praw jednostki. Jednym ze źródeł praw podatnika jest Karta Praw Podstawowych Unii Europejskiej. Na straży przestrzegania praw podstawowych wynikających z Karty stoją sądy krajowe i unijne: w Polsce, w sferze opodatkowania - sądy administracyjne. Celem niniejszego artykułu jest ustalenie, jak w praktyce sądów administracyjnych przedstawia się stosowanie standardów ochrony praw podatnika zagwarantowanych przez Kartę Praw Podstawowych. Analiza orzecznictwa sądów administracyjnych pozwoli na zweryfikowanie hipotez odnoszących się do charakteru i potencjału unijnych standardów ochrony praw podatnika, a także sposobu ich wykorzystania w razie ewentualnego naruszenia tych praw przez państwo członkowskie. W artykule zostanie podjęta próba zweryfikowania następujących hipotez:

- standardy ochrony praw podatnika wynikające z Karty Praw Podstawowych nie znajdują częstego zastosowania w orzecznictwie sądów administracyjnych;

- Karta Praw Podstawowych nie jest prawidłowo stosowana przez sądy administracyjne;

Dr AgnieszKa FranczaK - adiunkt w Katedrze Prawa Nieruchomości i Prawa Podatkowego, Instytut Prawa, Kolegium Ekonomii, Finansów i Prawa Uniwersytetu Ekonomicznego w Krakowie, ul. Rakowicka 27, 31-510 Kraków; e-mail: franczak@uek.krakow.pl; https://orcid.org/0000-00019393-634X 
- istnieje korelacja pomiędzy odwołaniem się przez Sąd w uzasadnieniu wyroku do przepisów wyrażających prawa podstawowe a przyznaniem racji podatnikowi (wygranie sprawy przez podatnika).

Aby osiągnąć załażony cel badawczy i zweryfikować postawione na wstępie hipotezy, badaniem empirycznym objęte będą orzeczenia sądów administracyjnych w sprawach podatkowych pochodzące z Centralnej Bazy Orzeczeń Sądów Administracyjnych [dalej cyt.: CBOSA] z ostatnich pięciu lat, tj. wydanych w okresie od 1 stycznia 2015 r. do 30 listopada 2019 r. Analiza przeprowadzona w pracy odnosić się będzie głównie do prawa Unii Europejskiej, a stan prawny na tle polskiego prawa zostanie uwzględniony jedynie $\mathrm{w}$ takim zakresie, $\mathrm{w}$ jakim bedzie to niezbędne dla prawidłowego toku wywodów. W artykule zostanie zastosowana metoda dogmatyczna analizy zjawisk prawnych oraz wnioskowanie statystyczne. Poddane będą analizie i odpowiedniej interpretacji źródła prawa unijnego, orzeczenia Trybunału Sprawiedliwości Unii Europejskiej [dalej cyt.: TSUE] i przede wszystkim sądów administracyjnych. Osiągnięcie celu badawczego wymagało będzie również poddania analizie i ocenie stanowisk polskich oraz zagranicznych przedstawicieli nauki prawa unijnego wyrażonych w publikacjach naukowych.

\section{ISTOTA KARTY PRAW PODSTAWOWYCH}

Karta to zbiór pięćdziesięciu fundamentalnych praw człowieka i obowiązków obywatelskich. Początkowo została podpisana 7 grudnia 2000 r. w Nicei jedynie jako polityczna deklaracja Parlamentu Europejskiego, Rady UE oraz Komisji Europejskiej. Moc wiążąca została nadana Karcie Praw Podstawowych dopiero przez Traktat Lizboński ${ }^{1}$, który wszedł w życie 1 grudnia 2009 r. Struktura Karty przypomina umowę międzynarodową. Składa się z siedmiu rozdziałów i 54 artkułów poprzedzonych preambułą. Poszczególne prawa zawarte zostały w szczęściu tematycznych rozdziałach Karty: „Godność”, „Wolność”, „Równość”, „Solidarność”, „Prawa obywatelskie” oraz „Wymiar sprawiedliwości”. Ostatni - siódmy rozdział - „Postanowienia ogólne dotyczące wykładni i stosowania Karty” dotyczy interpretacji i zakresu zastosowania Karty.

Karta stanowi integralną część prawa pierwotnego Unii. W Preambule podkreślono, że Karta potwierdza, przy poszanowaniu kompetencji i zadań Unii oraz zasady pomocniczości, prawa wynikające zwłaszcza z tradycji konstytucyjnych i zobowiązań międzynarodowych wspólnych Państwom Członkowskim, Euro-

\footnotetext{
${ }^{1}$ Traktat z Lizbony zmieniający Traktat o Unii Europejskiej i Traktat ustanawiający Wspólnotę Europejską podpisany w Lizbonie dnia 13 grudnia 2007 r., Dz. U. UE 2007/C 306/01.
} 
pejskiej Konwencji o Ochronie Praw Człowieka i Podstawowych Wolności, Kart Społecznych przyjętych przez Unię i Radę Europy oraz z orzecznictwa Trybunału Sprawiedliwości Unii Europejskiej i Europejskiego Trybunału Praw Człowieka. W tym kontekście, sądy Unii i Państw Członkowskich będą interpretowały Kartę z należytym uwzględnieniem wyjaśnień sporządzonych pod kierownictwem Prezydium Konwentu Europejskiego, który opracował Kartę, i za których uaktualnienie także odpowiada wspomniane Prezydium.

Zgodnie z art. 6 ust. 1 Traktatu o Unii Europejskiej ${ }^{2}$ Unia uznaje prawa, wolności i zasady określone w Karcie praw podstawowych Unii Europejskiej z 7 grudnia 2000 r., w brzmieniu dostosowanym 12 grudnia 2007 r. w Strasburgu, która ma taką samą moc prawną jak Traktaty. Stąd też w świetle wyżej wymienionego przepisu porządek prawny Unii zawiera pisemny, prawnie wiążący katalog praw podstawowych, który jest równy z Traktatami. Postanowienia Karty w żaden sposób nie rozszerzają kompetencji Unii określonych w Traktatach. Natomiast prawa, wolności i zasady zawarte w Karcie są interpretowane zgodnie z postanowieniami ogólnymi określonymi w tytule VII Karty regulującymi jej interpretację i stosowanie oraz z należytym uwzględnieniem wyjaśnień, o których mowa w Karcie, które określają źródła tych postanowień.

Podsumowując, dzięki nadaniu Karcie statusu prawnego równego traktatom Karta Praw Podstawowych zyskała rangę prawa pierwotnego. Z kolei ochrona praw podatnika, rozszerzona i wzmocniona przez Kartę uzyskała podstawę w prawie pierwotnym Unii Europejskiej.

\section{ZAKRES ZASTOSOWANIA KARTY WOBEC PAŃSTW CZŁONKOWSKICH W SFERZE OPODATKOWANIA}

Postanowienia Karty zgodnie z art. 51 ust.1 Karty mają zastosowanie do instytucji, organów i jednostek organizacyjnych Unii przy poszanowaniu zasady pomocniczości oraz do Państw Członkowskich wyłącznie w zakresie, w jakim stosują one prawo Unii. Szanują one więc prawa, przestrzegają zasad i popierają ich stosowanie zgodnie ze swymi odpowiednimi uprawnieniami i w poszanowaniu granic kompetencji Unii powierzonych jej w Traktatach. Karta zakreśla zatem granice je stosowania do prawa Unii. Wyrażenie wyłącznie w zakresie, w jakim (państwa członkowskie) stosują prawo Unii, powinno dotyczyć wszystkich sytuacji, w których państwa członkowskie wypełniają swoje zobowiązania nałożone

${ }^{2}$ Traktat o Unii Europejskiej z dnia 7 lutego 1992 r., wersja skonsolidowana: Dz. Urz. UE C 202 z 2016 r., s. 13. 
przez prawo unijne, a więc zarówno w zakresie stanowienia jak i stosowanie prawa podatkowego. I odwrotnie, gdy prawo unijne nie nakłada zobowiązań na państwa członkowskie, Karta nie ma zastosowania. Kwestie zakresu stosowania Katy Praw Podstawowych do państw członkowskich dobitnie wyjaśnił TSUE w wyrokach w sprawie Akerberg Fransson 3 oraz Siragusa ${ }^{4}$. TSUE zinterpretował ten przepis w taki sposób, że poszanowanie praw podstawowych chronionych na mocy Karty jest $[\ldots]$ konieczne w sytuacji, gdy przepisy krajowe mieszczą się w zakresie zastosowania prawa Unii. Trybunał wskazał, że respektowanie prawa Unii oznacza jednoczesne przestrzeganie praw podstawowych chronionych na mocy Karty. Oznacza to, że co prawda Karta Praw Podstawowych jako prawo pierwotne jest częścią porządku prawnego Unii Europejskiej, ale zarzut naruszenia postanowień Karty może być podnoszony tylko w sytuacji, gdy w sprawie mają zastosowanie lub powinny mieć zastosowanie inne niż Karta przepisy prawa Unii Europejskiej. Tym samym zarzut naruszenia przepisów Karty Praw Podstawowych nie może stanowić samodzielnej podstawy skargi. W kolejnych wyrokach TSUE podkreślił, że pojęcie stosowania prawa Unii w rozumieniu art. 51 ust. 1 Karty wymaga istnienia powiązania określonego stopnia z prawem Unii i że jeżeli stan prawny nie jest objęty zakresem stosowania prawa Unii, Trybunał nie jest właściwy do jego oceny, a przytaczane ewentualne postanowienia Karty nie mogą stanowić samodzielnej podstawy do nadania mu takiej właściwości ${ }^{5}$. Specyfika unijnych praw podstawowych, w świetle przytoczonych wyroków, polega zatem na szukaniu odpowiedniego łącznika z prawem Unii. Sprawą unijną (z elementem unijnym) będzie każda sprawa sądowa, której przedmiot pozostaje w związku z prawem unijnym np. przez skorzystanie ze swobód rynku wewnętrznego, bezpośrednie zastosowanie przepisów traktatowych lub rozporządzenia albo wykładnię przepisów krajowych transponujących dyrektywy do porządku krajowego ${ }^{6}$. W sferze opodatkowania taki łącznik występuję bądź może występować między innymi w sprawach dotyczących VAT, podatku akcyzowego, w postępowaniach podatkowych czy postępowaniach karno-skarbowych.

\footnotetext{
${ }^{3}$ Wyrok TSUE z dnia 26 lutego 2013 r. w sprawę C-617/10, Åklagaren przeciwko Hans Åkerberg Fransson, pkt 21.

${ }^{4}$ Wyrok TSUE z dnia 6 marca 2014 r. w sprawie C-206/13, Cruciano Siragusa przeciwko Regione Sicilia - Soprintendenza Beni Culturali e Ambientali di Palermo.

${ }^{5}$ Wyrok TSUE z dnia 27 marca 2014 r. w sprawie C-265/13 Emiliano Torralbo Marcos, pkt 30; wyrok TSUE z dnia 6 marca 2014 r. w sprawie C-206/13, Cruciano Siragusa przeciwko Regione Sicilia - Soprintendenza Beni Culturali e Ambientali di Palermo, pkt 24.

${ }^{6}$ R. Grzeszczak, A. Szmigielski, Sadowe stosowanie Karty Praw Podstawowych UE w odniesieniu do państw członkowskich - refleksje na podstawie orzecznictwa Trybunatu Sprawiedliwości i praktyki sądów krajowych, „Europejski Przegląd Sądowy” 10 (2015), s. 13.
} 
Zgodnie z ust. 2 analizowanego artykułu Karta nie rozszerza zakresu zastosowania prawa Unii poza kompetencje Unii, nie ustanawia nowych kompetencji ani zadań Unii, ani też nie zmienia kompetencji i zadań określonych w Traktatach. Przy interpretacji art. 51 Karty należy uwzględniać zasadę przyznania przewidzianą w art. 5 ust. 2 TUE. Zgodnie z zasadą przyznania Unia działa wyłącznie w granicach kompetencji przyznanych jej przez Państwa Członkowskie w Traktatach do osiągnięcia określonych w nich celów. Wszelkie kompetencje nieprzyznane Unii w Traktatach należą do Państw Członkowskich. Z kolei zgodnie z zasadą pomocniczości zawartą w art. 5 ust. 3 TUE, w dziedzinach, które nie należą do jej wyłącznej kompetencji, Unia podejmuje działania tylko wówczas i tylko w takim zakresie, w jakim cele zamierzonego działania nie mogą zostać osiągnięte w sposób wystarczający przez Państwa Członkowskie, zarówno na poziomie centralnym, jak i regionalnym oraz lokalnym, i jeśli ze względu na rozmiary lub skutki proponowanego działania możliwe jest lepsze ich osiągnięcie na poziomie Unii.

\section{KARTA PRAW PODSTAWOWYCH}

\section{A INNE ŹRÓDŁA PRAW PODATNIKA}

Karta Praw Podstawowych stanowi tylko jeden z filarów praw podstawowych Unii Europejskiej, w tym praw podatnika. W ust. 2 i 3 art. 6 TUE zostały wymienione inne źródła, a mianowicie wskazano, że prawa podstawowe zagwarantowane w europejskiej Konwencji o ochronie praw człowieka i podstawowych wolności oraz wynikające z tradycji konstytucyjnych wspólnych Państwom Członkowskim, stanowią część prawa Unii jako zasady ogólne prawa. W rezultacie tych postanowień ochrona praw podstawowych w Unii Europejskiej opiera się na trzech filarach traktatowych, a mianowicie: Karcie Praw Podstawowych, akcesji Unii do Europejskiej Konwencji o Ochronie Praw Człowieka i Podstawowych Wolności [dalej cyt.: EKPCz] oraz prawach podstawowych jako zasadach ogólnych (prawa unijnego) ${ }^{7}$. W doktrynie część autorów krytykuje kompleksową strukturę art. 6. TUE ze względu na szeroki zakres źródeł praw podstawowych, co może budzić wątpliwości i niepewność sytuacji prawnej jednostki ${ }^{8}$. Z kolei inni autorzy traktują to jako okazję do zapełnienia luk w Karcie i uniknięcia katalogowania praw podstawowych w formie jednego tekstu normatywnego, który - jakkolwiek kompletny - może w pewnym momencie nie odpowiadać na potrzeby rozwijających

\footnotetext{
${ }^{7}$ Karta Praw Podstawowych Unii Europejskiej. Komentarz, red. A. Wróbel, Warszawa: C.H. Beck 2013.

8 Tamże.
} 
się społeczeństw ${ }^{9}$. Nie mniej należy podkreślić, że takie sformułowanie art. 6 TUE pozwala na szerszą interpretację praw zagwarantowanych w Karcie ${ }^{10}$. Istotne jest również to, że art. 6 TUE podobnie jak art. 51 Karty gwarantuje, że postanowienia Karty w żaden sposób nie rozszerzają kompetencji Unii określonych w Traktatach.

W praktyce wybór właściwego standardu ochrony praw podatnika wywołuje wiele wątpliwości i to zarówno w perspektywie krajowej, jak i unijnej. Wątpliwości sprowadzają się między innymi do pytania, czy powinien być stosowany standard krajowy - konstytucyjny, czy standard wynikający z EKPCz, albo może standard z Karty. Kwestie wzajemnych relacji praw podstawowych Unii Europejskiej oraz praw zawartych w krajowych porządkach prawnych państw członkowskich zostały uregulowane w art. 52 Karty. Zgodnie z art. 52 ust. 3 Karty w zakresie, w jakim Karta zawiera prawa, które odpowiadają prawom zagwarantowanym w EKPCz, ich znaczenie i zakres są takie same jak praw przyznanych przez tę Konwencję. Postanowienie art. 52 ust. 3 Karty nie stanowi przeszkody, aby prawo Unii przyznawało szerszą ochronę. Należy zauważyć, że EKPCz miała podstawowe znaczenie w procesie kształtowania katalogu praw podstawowych Unii, ich treści, struktury i ochrony. Ten wpływ przejawia się to w tym, że, Konwencja była zasadniczym źródłem konstruowania przez sądy unijne praw podstawowych jako zasad ogólnych prawa unijnego, co potwierdza obecne brzmienie art. 6 TUE ${ }^{11}$. Ponadto wiele przepisów EKPCz było albo wzorem przepisów Karty, albo zostało prawie dosłownie przejęte do Karty ${ }^{12}$. Przy czym należy podkreślić, że Karta Praw Podstawowych w porównaniu z EKPCz zawiera niezwykle szeroki katalog praw gwarantowanych. Natomiast główna część tekstu Konwencji jest niezwykle lakoniczna i składa się z przepisów wyrażających podstawowe prawa polityczne zaliczane do pierwszej generacji praw człowieka (art. 2-14), ponadto zawiera kilka reguł dotyczących zagwarantowania praw przez państwo-stronę (art.1), możliwości derogacji i ograniczania praw (art. 15-16 i 18) oraz korzystania z praw (art.17). Pozostała część Konwencji to reguły proceduralne i tzw. przepisy różne ${ }^{13}$. Poza prawami zapisanymi w głównym tekście Konwencji istnieje kilka protokołów dodatkowych dotyczących praw, które okazały się politycznie „kłopotliwe”. Nawet jednak protokoły dodatkowe nie obejmują wielu obszarów materii, które są

\footnotetext{
${ }^{9}$ Ł. Bojarski, D. Schindlauer, K. Wladasch [i in.], Karta Praw Podstawowych Unii Europejskiej jako żywy instrument. Podręcznik dla prawników, red. M. Wróblewski, Warszawa: Ośrodek Badań Studiów i Legislacji 2014, s. 23.

${ }^{10}$ Tamże.

${ }^{11}$ Karta Praw Podstawowych Unii Europejskiej. Komentarz.

${ }^{12}$ B. Brzeziński, Prawo podatkowe. Zagadnienia teorii i praktyki, Toruń: TNOiK 2017, s. 578.

${ }^{13}$ Tamże.
} 
współcześnie zaliczane do szeroko rozumianych praw człowieka ${ }^{14}$. Niewątpliwie Karta w zestawieniu z Konwencją zawiera dużo większy katalog praw.

Z kolei zgodnie z art. 52 ust. 4 Karty w zakresie, w jakim Karta uznaje prawa podstawowe wynikające ze wspólnych tradycji konstytucyjnych Państw Członkowskich, prawa te interpretuje się zgodnie z tymi tradycjami. W literaturze podkreśla się, że podtrzymanie krajowego standardu ochrony praw podstawowych jest możliwe, o ile standard ten nie podważa poziomu ochrony wynikającego z Karty oraz nie narusza pierwszeństwa, jednolitości i skuteczności prawa Uni1 ${ }^{15}$. TSUE jednoznacznie dopuszcza stosowanie standardów konstytucyjnych wtedy, kiedy regulacje unijne nie są dostatecznie precyzyjne i znajdujemy się w obszarze znaczącej swobody regulacyjnej państw członkowskich, a jednocześnie ich stosowanie nie narusza zasady pierwszeństwa, efektywności i spójności prawa europejskiego ${ }^{16}$. W tym miejscu pojawia się kolejne pole do dyskusji, jakie tworzy pytanie, jak interpretować art. 53 Karty z punktu widzenia wartości, jaką jest tożsamość konstytucyjna państw członkowskich. Z przepisu tego wynika, że żadne z postanowień Karty nie będzie interpretowane jako ograniczające lub naruszające prawa człowieka i podstawowe wolności uznane, we właściwych im obszarach zastosowania, przez prawo Unii i prawo międzynarodowe oraz konwencje międzynarodowe, których Unia lub wszystkie Państwa Członkowskie są stronami, w szczególności przez EKPCz oraz przez konstytucje Państw Członkowskich. TSUE wskazał, że artykuł 53 Karty potwierdza wprawdzie, że gdy akt prawa Unii wymaga przyjęcia krajowych aktów stosowania, organy i sądy krajowe są uprawnione do stosowania krajowych standardów ochrony praw podstawowych, o ile zastosowanie owych standardów nie podważa poziomu ochrony wynikającego z Karty stosownie do wykładni Trybunału, ani pierwszeństwa, jednolitości i skuteczności prawa Unii ${ }^{17}$. Można zatem przyjąć dwie granice stosowania Karty Praw Podstawowych w relacji do standardów krajowych ${ }^{18}$. Dolna granica to minimalny poziom ochrony. Gdy prawo krajowe przewiduje niższy standard ochrony podatnika, konieczne jest

14 Tamże.

${ }^{15}$ D. Dominik-OgińsKa, Karta Praw Podstawowych Unii Europejskiej i jej stosowanie w podatkach, „Kwartalnik Doradca Podatkowy” 3 (2019), s. 42; M. TAвorowski, Znaczenie art. 53 Karty Praw Podstawowych Unii Europejskiej dla poziomu ochrony praw podstawowych $w$ krajowym prawie konstytucyjnym, „Państwo i Prawo” 1 (2016), s. 43.

${ }^{16}$ Wyrok TSUE z dnia 26 lutego 2013 r, w sprawie C-399/11 Stefano Melloni przeciwko Ministerio Fiscal.

17 Tamże.

${ }^{18}$ Por. np. M. SAfJan, Dyskusja, [w:] Stosowanie Karty Praw Podstawowych UE przez sady polskie. Konferencja zorganizowana przez Ministerstwo Spraw Zagranicznych, 25 września 2015 r., Warszawa: Ministerstwo Spraw Zagranicznych, Departament Polityki Europejskiej 2016, s. 49. 
zastosowanie standardu wynikającego z Karty ${ }^{19}$. Natomiast górna granica odnosi się do najwyższego możliwego standardu ochrony. Organy państw członkowskich mogą stosować krajowy standard praw podstawowych, nawet wyższy od standardu z Karty, jeżeli tylko nie narusza pierwszeństwa, jednolitości i skuteczności prawa Unii ${ }^{20}$. Należy się w tym miejscu zgodzić ze stanowiskiem prezentowanym w doktrynie i stanowiskiem TSUE w sprawie Åkerberg Fransson, że kluczowy dla sprawy jest stopień szczegółowości regulacji danego zagadnienia na poziomie Unii $^{21}$. W sytuacji, gdy w przepisach prawa Unii zostało w pełni określone działanie państw członkowskich, to standard Karty będzie zarówno poziomem minimalnym, jak i poziomem maksymalnym ochrony praw podatnika.

\section{STOSOWANIE PRAW PODSTAWOWYCH GWARANTOWANYCH NA MOCY KARTY PRZEZ SĄDY ADMINISTRACYJNE}

Prawo Unii Europejskiej stanowi integralną część systemów prawnych państw członkowskich. To powoduje, że sądy krajowe zobowiązane są do stosowania Karty Praw Podstawowych we wszystkich sprawach mieszczących się w zakresie jej zastosowania ${ }^{22}$. Szeroki zakres zastosowania Karty Praw Podstawowych powoduje, że sądy administracyjne uzyskały rolę unijnych sądów konstytucyjnych badających nie tylko zgodność prawa krajowego z prawem unijnym, lecz także zgodność prawa krajowego z prawami podstawowymi uznanymi w systemie Unii. Prawo do sądu uregulowane i gwarantowane w przepisach unijnych oznacza konieczność zapewnienia ochrony sądowej roszczeń unijnych polegającej na możliwości wniesienia sprawy do sądu w ramach dowolnego, regulowanego prawem krajowym postępowania sądowego, które spełni warunek skuteczności i równoważności ${ }^{23}$. Dostęp do sądu krajowego jest konieczną konsekwencją doktryny bezpośredniego skutku i pierwszeństwa stosowania prawa unijnego ${ }^{24}$. Powyższe oznacza, że sędzia administracyjny zobowiązany jest interpretować prawo podatkowe i kontrolować działania administracji podatkowej w zgodzie z prawami

\footnotetext{
19 TABorowsKi, Znaczenie art. 53 Karty, s. 43.

20 Tamże.

${ }^{21}$ Tamże, s. 44.

${ }^{22}$ Unijne uprawnienia sądów krajowych mają swoje umocowanie w traktatach: art. 267 Traktatu o funkcjonowaniu Unii Europejskiej oraz pośrednio w art. 19 ust. 1 zd. 2 TUE i art. 7 TUE.

${ }^{23}$ Por. N. PóŁtorak, Ochrona uprawnień wynikajacych z prawa Unii Europejskiej w postępowaniach krajowych, Warszawa: Wolters Kluwer Polska 2010, s. 165.

${ }^{24}$ Tamże, s. 177.
} 
podstawowymi. Zapewnienie właściwej ochrony praw podatnika na mocy Karty dotyczy już etapu rozstrzygania sporu przez wojewódzki sąd administracyjny ${ }^{25}$. Sąd krajowy nie może jednak samodzielnie podważyć przepisu prawa Unii jako być może niezgodnego z prawami podstawowymi ${ }^{26}$. W tym celu musi się zwrócić do TSUE, który ma właściwość stwierdzania nieważności prawa pochodnego Unii $\mathrm{w}$ trybie prejudycjalnym z art. 267 TFUE $^{27}$.

Sąd administracyjny na początku podejmowanych rozważań prawnych powinien dokonać oceny, czy dana sprawa stanowi sprawę z zakresu prawa Unii. Kwalifikacja charakteru sprawy determinuje bowiem możliwość/obowiązek dalszych czynności merytorycznych podejmowanych przez sąd krajowy ${ }^{28}$. Prawidłowa ocena przez sąd administracyjny charakteru sprawy rzutować będzie na możliwość zastosowania Karty Praw Podstawowych i zgodność z prawem unijnym wydanego rozstrzygnięcia ${ }^{29}$. W literaturze negatywnie ocenia się praktykę sądów administracyjnych w zakresie stosowania art. 51 ust. 1 Karty. Wskazuje się, że polskie sądy administracyjne praktycznie nie zadają sobie trudu analizy, czy w danej sprawie Karta będzie mieć w ogóle zastosowanie ${ }^{30}$. Zdaniem N. Półtorak wykorzystywany jest schemat postępowania, jaki sądy administracyjne przyjmują w odniesieniu do EKPCz, która generalnie tylko w uzupełniający sposób jest powoływana w orzecznictwie ${ }^{31}$. Karta, podobnie jak EKPCz, nie jest traktowana jak podstawa rozstrzygnięcia, a jedynie jako potwierdzenie rozstrzygnięcia wydanego na podstawie polskiego prawa podatkowego.

Podatnik w postępowaniu przed sądem administracyjnym może sam wysuwać odpowiednie roszczenia w celu uwzględnienia przez sąd administracyjny praw gwarantowanych w Karcie ${ }^{32}$. W sytuacji jednak, gdy strona nie wysuwa takich

${ }^{25}$ F. Casarosa, F. Fontanelli, N. Lazzerini [i in.], Metody interakcji sadowych $w$ sprawach dotyczacych europejskich praw podstawowych, oprac. wersji polskiej Wydział Prawa Europejskiego Biura Orzecznictwa Naczelnego Sądu Administracyjnego, Warszawa: Naczelny Sąd Administracyjny 2014, s. 14.

${ }^{26}$ GrzeszcZak, SzMigielski, Sadowe stosowanie, s. 15.

${ }^{27}$ Dz. Urz. UE C 326 z 2012 r., s. 47 [dalej cyt.: TFUE]; wyrok TSUE z dnia 8 kwietnia 2014 r., w sprawach C-293/12 i C-594/12, Digital Rights Ireland, EU:C:2014:238.

${ }^{28}$ M. BARAN, Stosowanie z urzędu prawa Unii Europejskiej przez sądy krajowe, Warszawa: Lex a Wolters Kluwer bussines 2014, s. 476.

${ }^{29}$ Tamże.

${ }^{30}$ Zob. np. N. PóŁtorak, Zakres związania państw członkowskich Karta Praw Podstawowych Unii Europejskiej, „Europejski Przegląd Sądowy” 9 (2014), s. 17; M. WróBLEwsKi, Karta Praw Podstawowych Unii Europejskiej w polskim sadownictwie - problemy $i$ wyzwania, „Kwartalnik Krajowej Rady Sądownictwa" 2 (2015), s. 18; J. BARCIK, Problematyka stosowania Karty Praw Podstawowych UE przez sady polskie, „Iustitia” 3 (2015), s. 153.

${ }^{31}$ PóŁtorak, Zakres zwiąania państw członkowskich, s. 17.

32 GrZeszczak, SzMigielski, Sądowe stosowanie, s. 15. 
roszczeń, a rozpatrywana sprawa może mieć łączność z prawem Unii, wojewódzki sąd administracyjny musi rozważyć zastosowanie Karty z urzędu ${ }^{33}$. Obowiązkiem sądu pierwszej instancji jest przeprowadzenie motu proprio kontroli naruszenia prawa krajowego i unijnego zarówno w aspekcie materialnym, jak i z punktu widzenia standardu proceduralnego ${ }^{34}$. Brak związania wojewódzkich sądów administracyjnych zarzutami i wnioskami skargi oznacza obowiązek podnoszenia z urzędu argumentów opartych na Karcie Praw Podstawowych ${ }^{35}$. Zgodnie z zakresem kognicji sądu administracyjnego orzekającego w pierwszej instancji bez znaczenia dla zakresu rozpoznania sprawy pozostaje postawa stron postępowania (zwłaszcza treść podniesionych w skardze zarzutów) ${ }^{36}$.

Wyzwanie, które stoi przed sądem administracyjnym wiąże się z pytaniem o moc normatywną danego przepisu i skutek prawny, który może on wywierać. Sąd administracyjny, aby prawidłowo zastosować przepisy Karty musi każdorazowo ustalić charakter przepisu, który zamierza zastosować (czy zawarte jest w nim prawo, czy zasada) ${ }^{37}$. Niektóre przepisy Karty mogą bowiem być bezpośrednio stosowane. Przypominają wówczas typowe prawa i wolności spotykane w konstytucjach państw członkowskich ${ }^{38}$. Część z nich z kolei przyjmuje postać zasad albo postanowień programowych, a więc posiada mniejszą wagę normatywną, szczególnie z punktu widzenia bezpośredniego stosowania Karty ${ }^{39}$. Sąd administracyjny powinien zatem ustalić, jakie obowiązki wynikają dla sądu przy stosowaniu konkretnego przepisu Karty. Są one różne w zależności od tego, czy przepis jest bezpośrednio skuteczny w relacji wertykalnej albo horyzontalnej, czy też nie ${ }^{40}$. Może również zajść potrzeba oceny proporcjonalności ingerencji w chronione prawo podstawowe.

Ponadto, co wskazano w poprzedniej części opracowania, sąd administracyjny musi ustalić relację przepisu Karty do przepisów innych źródeł praw podatnika. Prawa podatnika formalne zawarte są w kilku porządkach prawnych. Przy czym wielość źródeł prawa zapewniających ochronę podatnikowi powinna być postrzegana przez sąd administracyjny nie jako wada systemu, ale wprost przeciwnie - jako jego atut.

33 Tamże.

${ }^{34}$ Baran, Stosowanie z urzędu, s. 488.

${ }^{35}$ Zob. art. $134 \S 1$ ustawy z dnia 30 sierpnia 2002 r. - Prawo o postępowaniu przed sądami administracyjnymi, Dz. U. z 2019 r., poz. 2325.

${ }^{36}$ Baran, Stosowanie z urzędu, s. 488.

${ }^{37}$ GrZeszCZaK, SzMigielski, Sądowe stosowanie, s. 15.

38 Tamże, s. 16.

39 Tamże.

${ }^{40}$ M. TABorowsKI, Jak usprawnić stosowanie Karty Praw Podstawowych Unii Europejskiej przez sądy polskie, [w:] Stosowanie Karty Praw Podstawowych, s. 105. 
Podsumowując, powyżej zostało przedstawione podstawowe minimum czynności, jakie sąd administracyjny musi wykonać, aby prawidłowo zastosować Kartę Praw Podstawowych.

\section{WYNIKI BADAŃ EMPIRYCZNYCH}

Przy użyciu takich kryteriów wyszukiwania w CBOSA, jak zastosowanych łącznie, z odmianą sformułowań: „Karta Praw Podstawowych” i „podatek” wyłoniona została próba 445 orzeczeń sądów administracyjnych (wyroki, postanowienia, uchwały) pochodzących z okresu od stycznia 2015 r. do listopada 2019 r. W grupie orzeczeń wojewódzkich sądów administracyjnych dominowały orzeczenia: WSA w Warszawie (81), WSA w Gliwicach (52), WSA we Wrocławiu (35), WSA w Krakowie (33) i WSA w Białymstoku (20). Zastosowanie Karty Praw Podstawowych w sferze opodatkowania najrzadziej było analizowane przez WSA w Kielcach (2) oraz WSA w Opolu (3). W orzecznictwie NSA w badanym 5-letnim postanowienia Karta były przytaczane 117 razy.

Można w związku z tym sformułować wniosek, że standardy ochrony praw podatnika gwarantowane na mocy Karty nie są popularne w orzecznictwie podatkowym. Zastosowanie Karty w analizowanych orzeczeniach było wynikiem zarówno argumentacji stron, jak i faktu, że sąd z własnej woli postanowił do Karty sięgnąć. Oceniając praktykę sądów administracyjnych w zakresie zastosowania Karty Praw Podstawowych należy podkreślić, że w znacznej część przypadków, Karta była jedynie argumentem pomocniczym, swojego rodzaju „ozdobnikiem”, którego zastosowanie nie było odpowiednio uzasadnione.

Najczęściej powoływany przez sądy administracyjne w sprawach podatkowych był art. 41 Karty, gwarantujący prawo do dobrej administracji1 ${ }^{41}$. Artykuł 41 Karty był powoływany przede wszystkim w sprawach dotyczących skarg na przewlekłe prowadzenie przez organy podatkowe postępowania kontrolne. Ponadto istotna grupa spraw dotyczyła nieprawidłowości w zakresie prowadzonego przez organ podatkowy postępowania dowodowego - głównie w podatku od towarów i usług oraz podatku akcyzowym. Innym, równie często powoływanym prawem było wynikające z art. 47 Karty - prawo do skutecznego środka prawnego i dostępu

${ }^{41}$ Zob. np. wyrok WSA we Wrocławiu z dnia 8 października 2019 r., sygn. akt I SA/Wr 467/19; wyrok WSA w Krakowie z dnia 27 grudnia 2018 r., sygn. akt III SAB/Kr 133/18; wyrok WSA w O1sztynie z dnia 10 maja 2018 r., sygn. akt I SAB/Ol 1/18; wyrok WSA w Gliwicach z dnia 4 września 2019 r., sygn. akt III SA/G1 531/19. 
do bezstronnego sądu ${ }^{42}$. Spośród innych praw gwarantowanych przez Kartę Praw Podstawowych $\mathrm{w}$ analizowanym okresie zastosowanie w sferze opodatkowania znalazł: art. 1 Karty - godność; art. 7 Karty - poszanowanie życia prywatnego i rodzinnego; art. 15 Karty - wolność wyboru zawodu i prawo do podejmowania pracy; art. 16 Karty - wolność prowadzenia działalności gospodarczej; art. 17 Karty - prawo własności; art. 20 Karty - równość wobec prawa oraz art. 21 Karty - niedyskryminacja.

Przeprowadzona analiza orzecznictwa sądów administracyjnych potwierdza sformułowaną w pierwszej części opracowania hipotezę odnoszącą się do nieprawidłowości w zakresie stosowania Karty Praw Podstawowych w sferze opodatkowania. I tutaj należy zaakcentować poważny problem, a mianowicie ustalania przez sąd administracyjny zakresu przedmiotowego (interpretacji art. 51 Karty) ${ }^{43}$. Problem jest poważny, ponieważ sądy administracyjne w analizowanym okresie tego ustalenia bardzo często nie przeprowadzały. Odwołaniu się przez sąd do postanowień Karty nie towarzyszyła analiza, czy dana sprawa jest sprawą unijną w rozumieniu art. 51 Karty. Mamy zatem do czynienia z sytuacjami, w których sądy rozpatrują zarzut naruszenia Karty bez wcześniejszej analizy możliwości jej zastosowania $\mathrm{w}$ danej sprawie. Należy jednak podkreślić, że występują również orzeczenia, w których sąd administracyjny prawidłowo przeprowadza analizę możliwości zastosowania Karty. Jako przykład można wskazać fragment uzasadnienia wyroku WSA we Wrocławiu ${ }^{44}:$ „[...] niezbędne jest zatem w pierwszej kolejności ustalenie, czy decyzja zmieniająca rozliczenie podatnika, zawarte w korektach deklaracji VAT-7 w zakresie VAT za okres od stycznia do września 2013 r., stanowi akt stosowania prawa Unii. W ocenie Sądu decyzja zmieniająca rozliczenie podatnika zawarte w korektach deklaracji VAT-7 w zakresie VAT za okres od stycznia do września 2013 r. stanowi akt stosowania prawa Unii w rozumieniu art. 51 ust. 1 Karty, albowiem jest przypadkiem stosowania art. 2, art. 98, art. 250 ust. 1, art. 273 dyrektywy 112 i art. 325 Traktatu o Funkcjonowaniu Unii Europejskiej [...] Trybunał Sprawiedliwości podkreślił, że nie tylko sankcje podatkowe, ale także

${ }^{42}$ Zob. np. wyrok NSA z dnia 20 grudnia 2016 r., sygn. akt I FSK 744/15; wyrok WSA w Warszawie z dnia 24 października 2018 r., sygn. akt VI SA/Wa 487/18; wyrok WSA w Warszawie z dnia 16 października 2018 r., sygn. akt III SAB/Wa 21/18; wyrok WSA we Wrocławiu z dnia 8 października 2019 r., sygn. akt I SA/Wr 467/19; wyrok WSA we Wrocławiu z dnia 19 lutego 2019 r., sygn. akt I SA/Wr 85/18; wyrok WSA we Wrocławiu z dnia 20 kwietnia 2017 r., sygn. akt I SAB/ Wr 29/16; wyrok WSA w Krakowie z dnia 20 marca 2017 r., sygn. akt I SAB/Kr 3/17; wyrok WSA w Krakowie z dnia 24 czerwca 2015 r., sygn. akt I SAB/Kr 5/15.

${ }^{43}$ Por. K. Kowalik-BańcZYK, Stosowanie KPP przez polskie sądy oraz przez organy władzy publicznej - przeglad orzecznictwa TK, SN, sądów powszechnych i administracyjnych, [w:] Stosowanie Karty Praw Podstawowych, s. 35.

${ }^{44}$ Zob. np. wyrok WSA we Wrocławiu z dnia 22 lipca 2019 r., sygn. akt I SA/Wr 365/19. 
postępowanie karne skarbowe z powodu podania nieprawdziwych informacji w zakresie VAT stanowią akt stosowania prawa Unii w rozumieniu art. 51 ust. 1 KPP”.

Należy zaważyć, że Karta jest wykorzystywana głównie jako dodatkowe poparcie zasadniczej argumentacji. Istotną tendencją występującą $\mathrm{w}$ analizowanym orzecznictwie jest zestawianie Karty Praw Podstawowych i EKPCz. Bardzo częstą praktyką jest powoływanie ,jednym tchem” obu źródeł praw podatnika ${ }^{45}$.

W analizowanych orzeczeniach nie występuje istotna korelacja pomiędzy przytoczeniem postanowień Karty Praw Podstawowych a przyznaniem racji podatnikowi (wygrana sprawy przez podatnika). Z próby wyłonionych orzeczeń tylko w kilku wojewódzkich sądach administracyjnych taka korelacja wystąpiła. Jest to jednak zbyt mała próba statystyczna, aby na jej podstawie wyciągać jakieś dalej idące wnioski . Trudno jednak wskazać, nawet w przypadku wspomnianych wyżej kilku wojewódzkich sądów administracyjnych, na bezpośrednie oddziaływanie Karty na rozstrzygnięcie sprawy. Korelację tę można bowiem wyjaśnić m.in. w ten sposób, że składy orzekające mogą być bardziej skłonne przyznać rację podatnikowi, gdy dostrzegą, że naruszenie praw podatnika podlega ocenie z punktu widzenia unijnego standardu. Ponadto może być też tak, że standard z Karty jest powołany wtedy, gdy niezależnie od niego sędziowie doszli już do wniosku, że naruszenie praw podatnika wystąpiło i zastosowali Kartę tylko jako dodatkowe poparcie zasadniczej argumentacji. Ten pogląd jest tym bardziej uzasadniony, że analiza wyłonionej próby orzeczeń dowodzi, że w uzasadnieniach zapadłych rozstrzygnięć Karta nie jest prawidłowo powoływana.

\section{PODSUMOWANIE}

Podsumowując powyższe rozważania można stwierdzić, że Karta Praw Podstawowych z jej dziesięcioletnią tradycją idealnie wpisuje się w niejasne i dynamicznie zmieniające się otoczenie prawne podatnika. Niewątpliwie skuteczność ochrony praw podatnika jest uzależniona od możliwości uwzględnienia przez sąd administracyjny praw zagwarantowanych w Karcie Praw Podstawowych i to niezależnie od stanowiska stron postępowania. Niestety, przedstawione powyżej wyniki badań empirycznych wskazują, że pomimo dziesięciu lat obowiązywania Karty jej stosowanie przez sądy administracyjne nie jest ani częste, ani pozbawione wad. Potencjalne problemy stojące na przeszkodzie częstszego sięgania po Kartę $\mathrm{w}$ postępowaniach $\mathrm{w}$ sferze opodatkowania wiążą się zarówno z kwestią skutecznego stosowania prawa Unii w ogóle, gdzie specyfika samej Karty wywo-

${ }^{45}$ Por. Kowalik-BańczyK, Stosowanie KPP, s. 33. 
łuje dodatkowe trudności, jak i małej świadomość praw gwarantowanych przez Kartę. Nie ma oczywiście jednej skutecznej, recepty na problemy związane ze stosowaniem Karty. Niemniej zbadanie, jak w praktyce sądów administracyjnych wygląda stosowanie standardów ochrony praw podatnika zagwarantowanych przez Kartę może stanowić pewien zalążek działań zaradczych, przyjęcia pewnego modelu postępowania i zwiększenia świadomości tych praw u podatników, doradców podatkowych oraz - last but not least - sędziów sądów administracyjnych.

\section{BIBLIOGRAFIA}

\section{ŹRÓDEA PRAWA}

Traktat o Funkcjonowaniu Unii Europejskiej z dnia 25 marca 1957 r., Dz. Urz. UE C 326 z 2012 r. Traktat o Unii Europejskiej z dnia 7 lutego 1992 r., Dz. Urz. UE C 202 z 2016 r.

Traktat z Lizbony zmieniający Traktat o Unii Europejskiej i Traktat ustanawiający Wspólnotę Europejską podpisany w Lizbonie z dnia 13 grudnia 2007 r., Dz. U. UE 2007/C 306/01.

Ustawa z dnia 30 sierpnia 2002 r. - Prawo o postępowaniu przed sądami administracyjnymi, Dz. U. z 2019 r., poz. 2325.

\section{ORZECZNICTWO}

Wyrok Trybunału Sprawiedliwości Unii Europejskiej z dnia 26 lutego 2013 r. w sprawę C-617/10, Åklagaren przeciwko Hans Åkerberg Fransson.

Wyrok Trybunału Sprawiedliwości Unii Europejskiej z dnia 26 lutego 2013 r. w sprawie C-399/11 Stefano Melloni przeciwko Ministerio Fiscal.

Wyrok Trybunału Sprawiedliwości Unii Europejskiej z dnia 6 marca 2014 r. w sprawie C-206/13,

Cruciano Siragusa przeciwko Regione Sicilia - Soprintendenza Beni Culturali e Ambientali di Palermo.

Wyrok Trybunału Sprawiedliwości Unii Europejskiej z dnia 27 marca 2014 r. w sprawie C-265/13 Emiliano Torralbo Marcos.

Wyrok Trybunału Sprawiedliwości Unii Europejskiej z dnia 8 kwietnia 2014 r. w sprawach C-293/12 i C-594/12, Digital Rights Ireland.

Wyrok Naczelnego Sądu Administracyjnego z dnia 20 grudnia 2016 r., sygn. akt I FSK 744/15.

Wyrok Wojewódzkiego Sądu Administracyjnego w Krakowie z dnia 24 czerwca 2015 r., sygn. akt I SAB/Kr 5/15.

Wyrok Wojewódzkiego Sądu Administracyjnego w Krakowie z dnia 20 marca 2017 r., sygn. akt I $\mathrm{SAB} / \mathrm{Kr} 3 / 17$.

Wyrok Wojewódzkiego Sądu Administracyjnego we Wrocławiu z dnia 20 kwietnia 2017 r., sygn. akt I SAB/Wr 29/16.

Wyrok Wojewódzkiego Sądu Administracyjnego w Olsztynie z dnia 10 maja 2018 r., sygn. akt I $\mathrm{SAB} / \mathrm{Ol} 1 / 18$.

Wyrok Wojewódzkiego Sądu Administracyjnego w Warszawie z dnia 16 października 2018 r., sygn. akt III SAB/Wa 21/18. 
Wyrok Wojewódzkiego Sądu Administracyjnego w Warszawie z dnia 24 października 2018 r., sygn. akt VI SA/Wa 487/18.

Wyrok Wojewódzkiego Sądu Administracyjnego w Krakowie z dnia 27 grudnia 2018 r., sygn. akt III SAB/Kr 133/18.

Wyrok Wojewódzkiego Sądu Administracyjnego we Wrocławiu z dnia 19 lutego 2019 r., sygn. akt I SA/Wr 85/18.

Wyrok Wojewódzkiego Sądu Administracyjnego we Wrocławiu z dnia 22 lipca 2019 r., sygn. akt I SA/Wr 365/19.

Wyrok Wojewódzkiego Sądu Administracyjnego w Gliwicach z dnia 4 września 2019 r., sygn. akt III SA/G1 531/19.

Wyrok Wojewódzkiego Sądu Administracyjnego we Wrocławiu z dnia 8 października 2019 r., sygn. akt I SA/Wr 467/19.

\section{LITERATURA}

BARAn Mariusz: Stosowanie z urzędu prawa Unii Europejskiej przez sądy krajowe, Warszawa: Lex a Wolters Kluwer bussines 2014.

BARCIK Jacek: Problematyka stosowania Karty Praw Podstawowych UE przez sądy polskie, Iustitia 3 (2015), s. 153-157.

Bojarski Łukasz, Schindlauer Dieter, Wladasch Katrin [i in.]: Karta Praw Podstawowych Unii Europejskiej jako żywy instrument. Podręcznik dla prawników, red. M. Wróblewski, Warszawa: Ośrodek Badań Studiów i Legislacji 2014.

BrzeZIŃsKi Bogumił: Prawo podatkowe. Zagadnienia teorii i praktyki, Toruń: TNOiK 2017.

Casarosa Federico, Fontanelli Filippo, Lazzerini Nicole [i in.]: Metody interakcji sądowych w sprawach dotyczących europejskich praw podstawowych, oprac. wersji polskiej Wydział Prawa Europejskiego Biura Orzecznictwa Naczelnego Sądu Administracyjnego, Warszawa: Naczelny Sąd Administracyjny 2014.

DominiK-Ogińska Dagmara: Karta Praw Podstawowych Unii Europejskiej i jej stosowanie w podatkach, Kwartalnik Doradca Podatkowy 3 (2019), s. 38-43.

GrZeszczak Robert, Szmigielski Artur: Sądowe stosowanie Karty Praw Podstawowych UE w odniesieniu do państw członkowskich - refleksje na podstawie orzecznictwa Trybunału Sprawiedliwości i praktyki sądów krajowych, Europejski Przegląd Sądowy 10 (2015), s. 11-18.

Karta Praw Podstawowych Unii Europejskiej. Komentarz, red. A. Wróbel, Warszawa: C.H. Beck 2013.

KowALIK-BAŃCZYK Krystyna: Stosowanie KPP przez polskie sądy oraz przez organy władzy publicznej - przegląd orzecznictwa TK, SN, sądów powszechnych i administracyjnych, [w:] Stosowanie Karty Praw Podstawowych UE przez sądy polskie. Konferencja zorganizowana przez Ministerstwo Spraw Zagranicznych, 25 września 2015 r., Warszawa: Ministerstwo Spraw Zagranicznych, Departament Polityki Europejskiej 2016, s. 33-39.

PóŁtoraK Nina: Zakres związania państw członkowskich Kartą Praw Podstawowych Unii Europejskiej, Europejski Przegląd Sądowy 9 (2014), s. 17-28.

PóŁtoraK Nina: Ochrona uprawnień wynikających z prawa Unii Europejskiej w postępowaniach krajowych, Warszawa: Wolters Kluwer Polska 2010.

SAFJan Marek: Dyskusja, [w:] Stosowanie Karty Praw Podstawowych UE przez sądy polskie. Konferencja zorganizowana przez Ministerstwo Spraw Zagranicznych, 25 września 2015 r., Warszawa: Ministerstwo Spraw Zagranicznych, Departament Polityki Europejskiej 2016, s. 44-52. 
TABOROwski Maciej: Jak usprawnić stosowanie Karty Praw Podstawowych Unii Europejskiej przez sądy polskie [w:] Stosowanie Karty Praw Podstawowych UE przez sądy polskie. Konferencja zorganizowana przez Ministerstwo Spraw Zagranicznych, 25 września 2015 r., Warszawa: Ministerstwo Spraw Zagranicznych, Departament Polityki Europejskiej 2016, s. 96-111.

TABOROwski Maciej: Znaczenie art. 53 Karty Praw Podstawowych Unii Europejskiej dla poziomu ochrony praw podstawowych w krajowym prawie konstytucyjnym, Państwo i Prawo 1 (2016), s. $40-57$.

WróBlewsKi Mirosław: Karta Praw Podstawowych Unii Europejskiej w polskim sądownictwie problemy i wyzwania, Kwartalnik Krajowej Rady Sadownictwa 2 (2015), s. 17-23.

\section{STANDARDY OCHRONY PRAW PODATNIKA W KARCIE PRAW PODSTAWOWYCH I ICH STOSOWANIE W ORZECZNICTWIE SĄDÓW ADMINISTRACYJNYCH}

\section{Streszczenie}

Jednym ze źródeł praw podatnika jest Karta Praw Podstawowych Unii Europejskiej. Współcześnie znaczenie praw podatnika gwarantowanych na mocy Karty jest coraz większe w związku ze koordynowanymi w skali międzynarodowej działaniami administracji podatkowej poszczególnych państw mającymi na celu zwalczanie unikania opodatkowania czy też uchylania się od opodatkowania. Na straży przestrzegania praw podstawowych wynikających z Karty stoją sądy krajowe i unijne: w Polsce, w sprawach podatkowych - sądy administracyjne. Celem niniejszego artykułu jest ustalenie, jak w praktyce sądów administracyjnych przedstawia się stosowanie standardów ochrony praw podatnika zagwarantowanych przez Kartę Praw Podstawowych. Aby osiągnąć założony cel badawczy i zweryfikować postawione hipotezy, badaniem empirycznym objęto orzeczenia sądów administracyjnych w sprawach podatkowych $\mathrm{z}$ ostatnich pięciu lat.

Słowa kluczowe: Karta Praw Podstawowych; prawa podatnika; prawo unijne; prawo podatkowe

\section{THE STANDARDS FOR THE PROTECTION OF TAXPAYER RIGHTS IN THE CHARTER OF FUNDAMENTAL RIGHTS OF THE EUROPEAN UNION AND THEIR APPLICATION IN THE JUDICATURE OF POLAND'S ADMINISTRATIVE COURTS}

\section{Sum mary}

One of the sources of taxpayer rights is the Charter of Fundamental Rights of the European Union. The current significance of taxpayer rights as guaranteed by said Charter increases due to international coordination by taxing authorities of individual states for the purpose of combating tax avoidance and/or evasion. Safeguarding these Charter fundamental rights are national and European Union courts: regarding tax issues in Poland, the administrative courts. This article determines how - in practice - Poland's administrative courts reflect and apply the taxpayer rights standards as defined by said Charter. In order to accomplish the research objective and verification of the proposed hypothesis, this empirical study examines the judicature of Poland's administrative courts in tax cases for the previous five years.

Key words: Charter of Fundamental Rights of the European Union; taxpayer rights; European Union laws; tax law 